\title{
Forensic autopsy: a handbook and atlas
}

\section{Pomara • S.B. Karch • V. Fineschi}

\author{
CRC Press, Taylor \& Francis Group \\ Boca Raton, FL, USA, 2010 \\ ISBN 978-1-4398-0064-5
}

Published online: 20 September 2010

(C) Springer-Verlag 2010

It is unusual to review a book dealing in a radiological journal that relates to autopsies, but the development of diagnostic imaging in all areas of medicine has led radiologists to use the most advanced diagnostic methods, applying them also to the fields of forensics and autopsy. As was brought to the fore at the recent SIRM Congress in Verona, "virtual autopsy" has made its powerful entry into the world of radiology, and our colleagues involved in legal medicine, as well as the judicial authorities, increasingly request the use of CT as a diagnostic aid during autopsies.

In many cases, the imaging technique is referred to as the "virtopsy"; that is to say, it is a virtual autopsy accomplished using CT, which can substitute for the autopsy undertaken on a dissecting table. However, as evidenced in the book, conventional autopsy remains irreplaceable, and cooperation between the two professions - forensic pathology and radiology - remains essential for the proper interpretation of any findings.

In this handsome volume, aimed primarily at forensic pathologists, there is a chapter on "Postmortem Radiology and Digital Imaging", edited by Professor Giuseppe Guglielmi, which covers this topic well and which may prove extremely useful to radiologists who are required to deal with this procedure.

In the immediate future, if radiologists choose not to become involved in the virtopsy field, they risk losing professional and scientific research opportunities that will be increasingly in demand as the area of legal medicine develops.
$\grave{E}$ insolito recensire in una rivista di radiologia un libro che tratta di autopsie, ma l'evoluzione della diagnostica per immagini in tutti gli ambiti di attività medica ha portato i radiologi ad utilizzare anche in campo forense ed autoptico le metodiche diagnostiche più avanzate. Come ben trattato al recente Congresso della Società Italiana di Radiologia Medica (SIRM) di Verona, l'autopsia virtuale ha fatto prepotentemente ingresso nel mondo radiologico e sempre più spesso è richiesto, dai colleghi medico legali o dalla autorità giudiziaria, di utilizzare la tomografia computerizzata (TC) come ausilio diagnostico per le autopsie.

In molti casi si ritiene che la virtopsy, cioè l'autopsia virtuale compiuta con la TC, possa sostituire quella effettuata al tavolo anatomico, ma, come dimostrato nel libro, l'esame autoptico rimane insostituibile e la collaborazione tra le due figure professionali del medico legale e del radiologo risulta essere indispensabile per la corretta interpretazione dei reperti.

In questo bel volume, dedicato soprattutto ai medici legali, vi è un capitolo dedicato "Postmortem Radiology and Digital Imaging”, curato dal prof. Giuseppe Guglielmi, che ben tratta questo argomento e che potrebbe essere estremamente utile ai radiologi che se ne dovessero occupare.

In un prossimo futuro, se $i$ radiologi non si interesseranno, con la specifica competenza, di tale settore, rischieranno di perdere una occasione di lavoro e di ricerca scientifica che sarà invece sempre più richiesta dalla evoluzione della medicina legale.

Adriano Fileni

Presidente Sezione Etica e Radiologia Forense Direttore UOC Diagnostica per Immagini POR INRCA- IRCCS Roma, Italy e-mail:a.fileni@inrca.it 